\title{
THE IMPORTANCE OF CONNECTING THE FIRST/LAST MILE TO PUBLIC TRANSPOR
}

\author{
Alica Kalašová, Kristián Čulík*, Miloš Poliak
}

Department of Road and Urban Transport, Faculty of Operation and Economics of Transport and Communications, University of Zilina, Zilina, Slovakia

*E-mail of corresponding author: kristian.culik@fpedas.uniza.sk

\section{Resume}

The first and last mile part of the public transport journey are essential for the whole transport system. Its quality affects the overall experience of the passenger in public transport. It is not important how attractive are individual transport modes if the rest of the journey is unattractive for the passenger. This paper is about shared mobility and it describes the connection between the first/last mile and the public transport system. Modes of shared mobility can reduce the pressure on the city transport system. It can also bring a better modal split. The authors performed a traffic-sociological survey for processing the respondents' opinions on the use of new modes of the sharing economy. The survey showed that more than eighty per cent of people travel to work daily, but more than half of them do not use public transport.

Available online: https://doi.org/10.26552/com.C.2022.2.A66-A78

\section{Article info}

Received 30 September 2021

Accepted 24 November 2021

Online 22 February 2022

\section{Keywords:}

first-/last-mile transport

public transport

demand

city

sharing economy

\section{Literature review}

The biggest problem of urban agglomerations today is the inefficient spatial and temporal movement of material flows. The solution is to find a compromise between time, quantity and space requirements of supply.

There are many points of view on city logistics. In most cases, it only deals with freight transport. For example, authors in [1] describe city logistics as a discipline specialized to cope with the sustainability problems encountered in urban freight transport. The authors in [2] highlight recent developments in modelling city logistics in three important areas; emissions, health care and mega-cities. The movement of people around the city is also an important topic. City logistics is about compliance with the set requirements in urban transport. It must also meet environmental and general economic conditions. In recent years, transport performance in urban transport has been increasing. There are several reasons, but the most significant is the increase in the transport of piece consignments in retail trade. Passenger transport is developing dynamically, too.

The main problem of the city logistics is traffic overloading. These congestions connected with traffic accidents have a negative influence on the environment. There are efforts to carry out the city logistics by environmentally friendly vehicles [3].
There are three similar terms for describing the freight flows in urban areas. These terms are city logistics, urban freight transport and urban goods movement. As stated in literature [4], the difference in terminology indicates differences in origin. The most commons are the term "city logistics." This term is from Germany, which developed the city logistics concept in the nineteen-nineties. The academic and professional literature provides definitions that are more accurate. Authors describe City logistics as the complexity of tasks [5-6].

The city logistics can improve the traffic situation in large cities and agglomerations. The Smart City concept can bring the solution to traffic problems. They have a close relationship with the quality of the environment and the life of inhabitants. Smart elements and technologies, implemented in the city logistics; increase the efficiency of the whole system. The main objective of the city logistics is to co-ordinate the most important activities like: freight transport, storage, inventory management, materials handling and all the related information processing in a way that meets customer requirements at optimum cost [7].

The "last-mile" delivery is the end part of a supply chain. According to [8], it is the least efficient stage of the supply chain and comprises up to $28 \%$ of the total delivery costs. Therefore, the improvement of the last mile logistics and a significant externalities reduction are very important challenges for researchers. Usually, it 


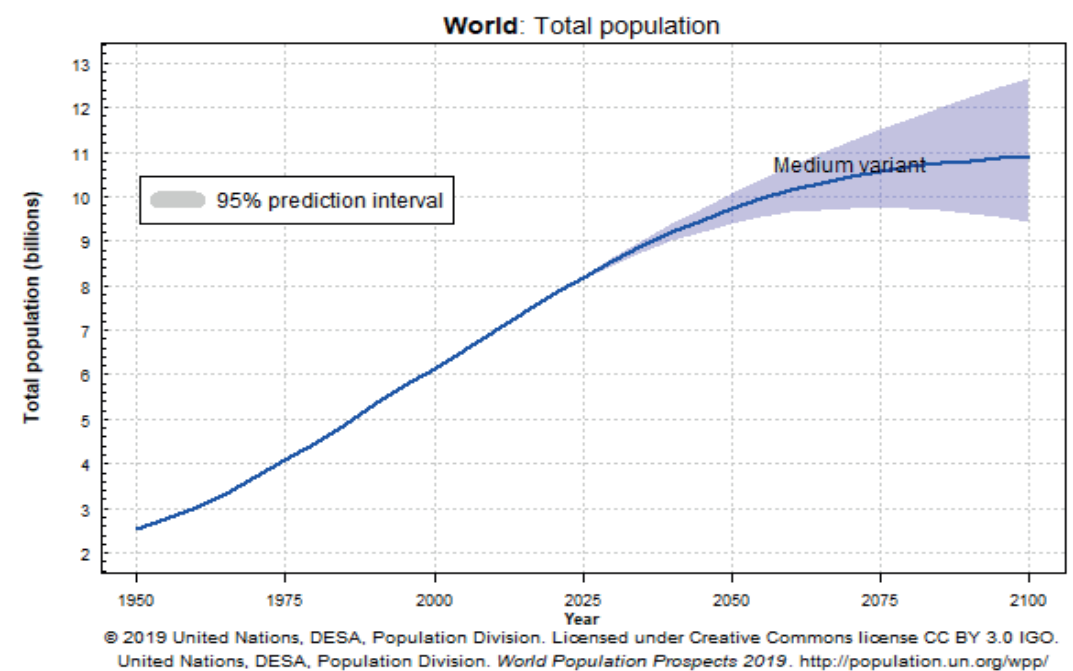

Figure 1 Total population of the world and its prediction [29]

is the most inefficient transport because the distribution of the receiving points is random and uneven. The low efficiency is connected with externalities in environment. Nowadays, there is a great demand for small, but very frequent shipments with delivery time windows. Delivery vehicles perform these delivery services and their operation is very ineffective in cities, where the city logistics system is not established. The problem is bigger with development of the e-commerce and increasing urbanization. Several improvements are described in literature [9-10]. Authors in [11] describe that the last mile of the supply chain is considered as one of the most, or even "the" most, expensive, inefficient and polluting part of the supply chain. One can improve this state by new sophisticated vehicles and optimization of the transport process. It can reduce the social and ecological impact of the traffic within the cities. In this article, are described the innovative methods and technologies for the "last-mile" transport. They can maintain the system sustainability from the view of the environment and business.

The "last-mile" delivery is the most challenging of the supply chain. It must ensure the transport from the supplier warehouse to the consumer's home. There are higher and higher requirements for the delivery time thanks to the e-commerce development and competitiveness between suppliers. The variable costs of the carriers or delivery companies must be as low as possible, so it is necessary to plan and schedule deliveries in advance [12].

According to many sources [13-15], the goal of city logistics is to create a sustainable and environmentally friendly transport system in the city. Cities use modern technologies from informatics, communications, well known as ITS (Intelligent Transport Systems).

According to [16-17], the transfer of people and goods across the city is more complicated than in the past. People spend a lot of time in public transport vehicles or their cars. The city logistics transport system must, according to the author, support mobility and reduce the travel time. One can ensure it by optimizing the stop time on intersections and reducing traffic congestions. The first and the last legs of a transport trip are very challenging from a planning perspective [18].

Public transport has a crucial impact on reducing the traffic congestions, fuel consumption and emission of carbon dioxide. It is essential to support using of the public transport and improve its accessibility. This way can ensure sustainable public transport in big cities. Comfort means are necessary for the first- and lastmile transportation because the aim is to reduce the travel time spent for transfer from home to the train/bus station or bus stop. Public transport can be attractive for passengers only when the first- and last-mile transport is comfortable, accessible and cost-effective [19-20].

The best solution for this problem is a shared mobility. The shared mobility is the use of a bicycle, electric bicycle, car, scooter, e-scooter or other transport means for a short time. Users gain short access to these transport modes on an as-needed basis. It should be highlighted that shared mobility includes the completely independent system as carsharing, carpooling, bikesharing or ridesharing. According to [21], the market for personal mobility is being changed quickly due to structural modifications of the social and cultural trends, as well as technological advances such as smartphones, Internet of Things (IoT) [22-23]. It can improve the public transport system consisting of bus, tram, trolleybus and train lines. These traditional transport modes have fixed routes, but the mentioned modes do not. Innovative transportation modes enhance urban mobility and give potential solutions to address the first- and last-mile connectivity with public transit. Therefore, they can significantly enhance the availability of public transport network. Usually, the main problem of public transport is the walking distance to the bus or tram stop or station. Alternative means of transport can fulfil this gap and resolve the first- and last-mile connectivity. The shared mobility transport modes are more flexible, cost-effective and they reduce the pressure 
on the road and parking infrastructure [24-26]. The most common system is a bikesharing. According to [2728 ], this system is capable to connect people with the public transport system.

\section{Introduction}

Cities have a high social and economic impact on society, but they also harm the environment. Figure 1 shows the population growth worldwide in recent years and the assumed forecast of the population development until the year 2100 . From the figure is obvious that over the last 35 years, the world's population has grown by more than 2.8 billion, which corresponds to an increase of more than $60 \%$ [15].

According to [30], more than $54 \%$ of the world's population already lives in cities. This share will probably increase to $60 \%$ in 2030 and even $70 \%$ in 2050. Such an increase will result in more than 60 million new city inhabitants per year. Cities generate $80 \%$ of the world's gross domestic product (GDP). On the other hand, they consume $75 \%$ of energy resources and produce $70 \%$ of greenhouse gas (GHG) emissions.

Nowadays, there is a high pressure on reducing the greenhouse gases. However, transport is not the only source of the problem. If people do not change the access to their lives, that will cause the water, food and energy crisis in future [31].

When the world becomes a city, cities will need to be smarter to address issues such as congestion, urban mobility, or resource management. Continued urbanization, together with the rapid development and introduction of new technologies, requires new ways of coping with the growing complexity of urban life. Smart cities are a unique opportunity to preserve the environment. The primary goal is to find a concept that will be able to provide cities with a sustainable model of development, excellent quality of life, safety and maximum energy efficiency. All these thanks to the use of the latest technologies. According to the Slovak Environmental Act, the sustainable model is "development that preserves the ability of current and future generations to meet their basic living needs without reducing the diversity of nature and preserves natural functions. The Smart City combines technology, government and society to enable smart economy, smart mobility, smart environment, smart people, smart living and smart governance of public ecosystems - Figure 2 [32].

Smart Cities require reasonable use of new technologies and interdisciplinary cooperation to create synergies between different areas, such as mobility, logistics, energy networks, or building structures, considering the use of resources and the goal of improving the quality of life.

Defining the concept of quality of life is very difficult because everyone imagines a quality of life differently. One of the definitions says that quality of life is the intangible aspect of life. These aspects are health, social relations and the quality of the natural environment, existing living conditions and personal well-being.

Authors want to emphasize that information and communication technologies are means, not a goal. The

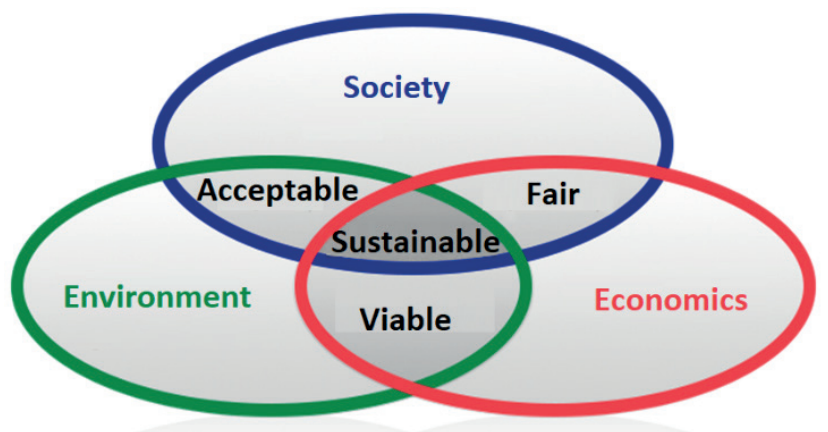

Figure 2 Relationship between the society, economy and the environment [33]
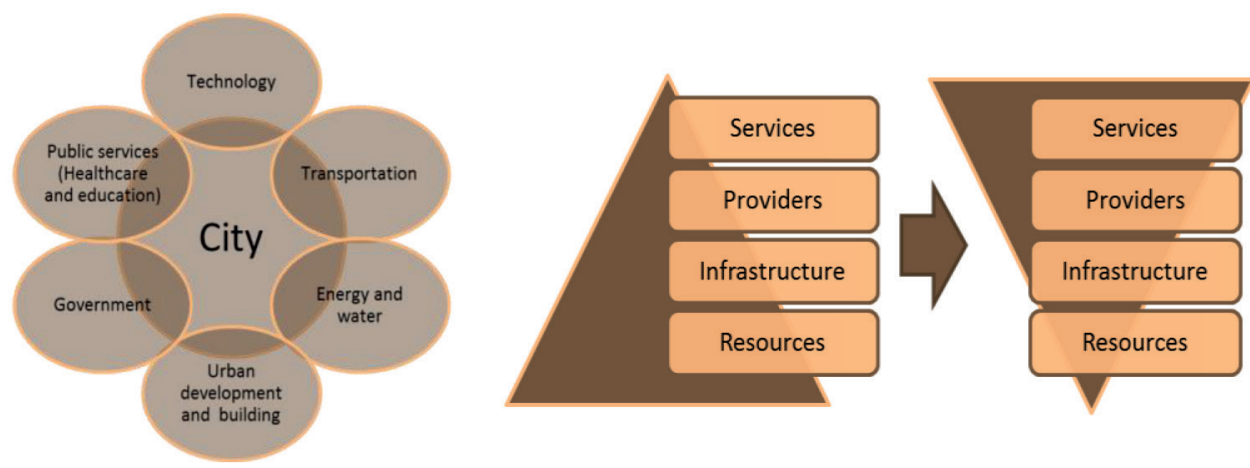

Figure 3 City as a service-focused system [34] 
goal is always to increase the quality of life. The human dimension of Smart Cities must exist. People need to be able to use new technologies. Importance of education, work with people, should be emphasized, as well. It is necessary to find out what inhabitants need. The true meaning of "smart" is to balance the relationship between people and technology. A real Smart City must not only be a technologically advanced city but a city-oriented city. From the point of view of systems sciences, one can consider a city as a system consisting of subsystems.

Authors in [34] understand the city as a complex system consisting of subsystems. Each subsystem, usually considered as independent, shares common goals - to create a city that is efficient, viable and sustainable. The concept of Smart Cities will consider several or all the subsystems at once using a common objective function aimed at improving the quality of life of the individual. This concept expects that subsystems work together and minimize the use of resources.

The current approach to the city subsystem focuses on infrastructure and resources. If one wants to improve the city, it is necessary to focus on the services provided to residents (Figure 3). The new goal is to provide the best services with minimal use of resources on a limited infrastructure. The city's subsystems must work together to achieve such a synergistic effect.

\section{Technologies of Smart Cities}

Technologies are means that enable the Smart Cities solutions. Smart Cities will collect, transmit and process Big Data. However, the data collected from the sensors is not information or knowledge. Big Data modelling will allow one to test new complex strategies in virtual space. With the introduction of the $5 \mathrm{G}-5$ th generation mobile network with high data rates, wide bandwidth and reduced latency times, large and highspeed data transmission will be widely available. The $5 \mathrm{G}$ network will enable the extensive development of the Internet of Things (IoT), a network of connected devices with real-time communication between devices. Examples of the IoT applications are as diverse as sensor data collection, vehicle-to-vehicle communication, vehicle-to-infrastructure communication, smart home. The IoT will then enable Internet Services (iOS), a layer of services based on the physical infrastructure of the Internet of Things [35].

The Internet of Things has a significant impact on the industry. The Fourth Industrial Revolution or Industry 4.0 is another step after the invention of the first programmable manufacturing robots in the nineteen-seventies. It is based on the CyberPhysical System (CPS), which combines physical manufacturing processes with computational processes through the creation of networks enabling the two-way communication, feedback and planning based on Big
Data analysis. Also, augmented reality will help human workers, such as pickers who wear headsets, that show them exactly where they can be picked up and where to place an item, which significantly reduces errors. Introduction of the $3 \mathrm{D}$ printing can provide rapid prototyping or even production customization.

Urban mobility will benefit from Smart Parking solutions, such as free parking and parking reservation. In the field of logistics, assembly plants are using Automated Guided Vehicles (AGVs). In the economy, new business models, based on the sharing economy, were developed.

The main purpose of smart cities is not the technologies themselves. Its main goal is to improve the quality of life of the citizens. It is not easy to meet this requirement. For example, if one introduces a new $5 \mathrm{G}$ mobile network, not all the users can use it. Another example from transport: when one builds a new smart parking lot, it will not improve the quality of life of all the people in the city. There is still a certain number of people without a car. Therefore, they cannot have a benefit from this improvement. The Smart City reduces the possibility to live in an old way.

In the field of transport, it is necessary to know the future demand for transport services and the expected volume of trips. One can estimate this demand from the people's activities. On the other hand, one also needs to know how people think and decide about their travelling. Synthetic models describe the actions of individual people in a day. If this pattern of activities and their locations is ready, the transport modelling is a very simple mathematical operation [36]. Of course, the transport demand of people is changing during their life. Therefore, it is significant to include the different age groups in modelling [37].

The Smart City must also provide a sustainable mobility for its citizens. The individual car transport is not sustainable, so there is a need for the public transport, which is currently experiencing problems. Figure 4 shows the modal split of passenger transport in Slovakia. The ratio between a car and public transport was 50:50 in 1995. The negative impacts changed the proportion to 74:26 in 2015 74:26. People use individual car transport more than the public transport. The average total costs of car ownership are up to $2,853 €$ per year. The unfavorable state of the modal split in the Slovak Republic has several causes. One can define a cycle of degradation of the public transport system. If fewer people use the public transport, it caused lower demand and lower sales. For this reason, the number of bus connections is reduced, which will further reduce the attractiveness of public transport. Another problem is unresolved connections. In Slovakia, the rail transport is ordered by the Ministry of Transport, suburban bus transport by the self-governing region and urban public transport by the city. The issue is also related to relatively affordable individual car transport. Restrictions on passenger cars in Slovak cities have not 


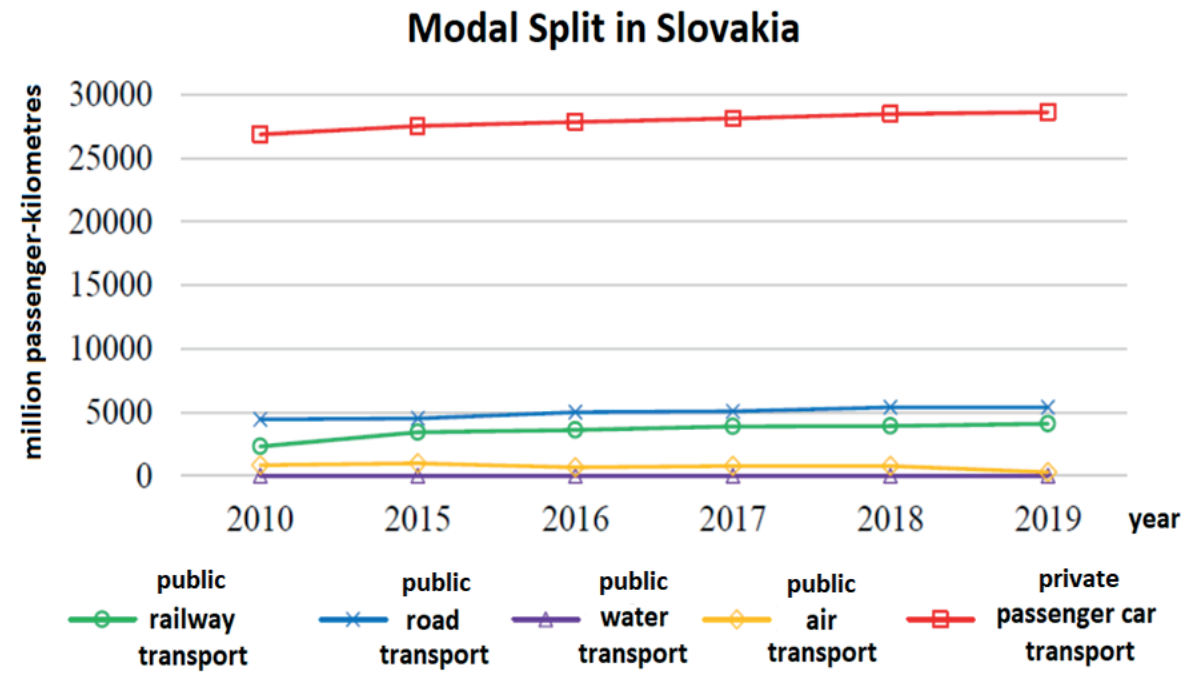

Figure 4 Modal split of passenger transport in Slovakia [38]

yet been introduced. The question is how to relocate people from their cars to different modes of transport? Several concepts, which are described in the following subsections, are important for the modal split.

\subsection{Tools of shared mobility}

Carsharing is a service that allows its customers to use a car without owning it or take care of its operation and maintenance. It can take various forms, from unofficial groups of friends sharing only one car and its costs to the bigger commercial forms. The commercial type has a professional organization with a strong technological and legal background. All these systems, if one wants to call them carsharing, must have several features in common:

- organized groups of users,

- few shared vehicles,

- wide network of vehicle parking stations near home, workplaces, or transport hubs,

- booking of vehicles before each ride,

- renting a vehicle for a short time (the rental time is shorter than in vehicle leasing),

- $\quad$ self-service access to vehicles.

Public bikesharing is a service that lends bicycles to people who do not own them. The main idea is to provide these bicycles free or at a symbolic price for short journeys in urban areas as an alternative to public or individual transport. They make the public transport network accessible to users. It means that they are ideal for the first- and last-mile transport. Bicycle sharing systems have two general categories:

- Bicycle rental organized without financial gain by organizations and communities.

- "Smart Bike" programs implemented by government agencies; they usually have own smartphone application, which ensures the right operation of the system.
Bicycle sharing programs have become increasingly popular in recent years, reflecting their ecological, inexpensive and comfortable advantages. They are insufficiently informed about research on cycling behavior associated with the dock-based bicycle sharing schemes. Authors in [39] investigated geographical groupings of docking stations using the spatial-temporal use. Other literature sources [40-42] identified the fleet balancing strategies for different station types and quantified the links between the bicycle demand and land use.

The bike-sharing systems were significantly improved by development of the IoT (Internet of Things). Nowadays, bicycles can be rented and returned to docking stations. However, one also has other systems, sometimes better for the first- or last-mile transport. Those systems have applications that allow returning bikes to any safe public area. Thanks to the application, people can easily find free bikes. Thanks to the GPS in all the bicycles, one can use data for transport planning. Logically, the bicycle sharing systems without dock stations provide more detailed and accurate data [43].

Bikesharing and carsharing are very different systems. They have various user groups and various limits. In the case of bikesharing as first-/last-mile transport, one should consider the following limits:

- the possibility of use depends on the physical condition of the cyclist,

- few docking stations or few bicycles in circulation,

- the unavailability of bicycles (quickly rented in places where there is a high demand - for example, the train station until noon),

- insufficient infrastructure (especially separate lanes and paths for cyclists)

- unsuitable (hilly) terrain in the area.

Carsharing is always a paid service. It has several limits, as well:

- high user prices,

- an underdeveloped form in Slovak conditions, 


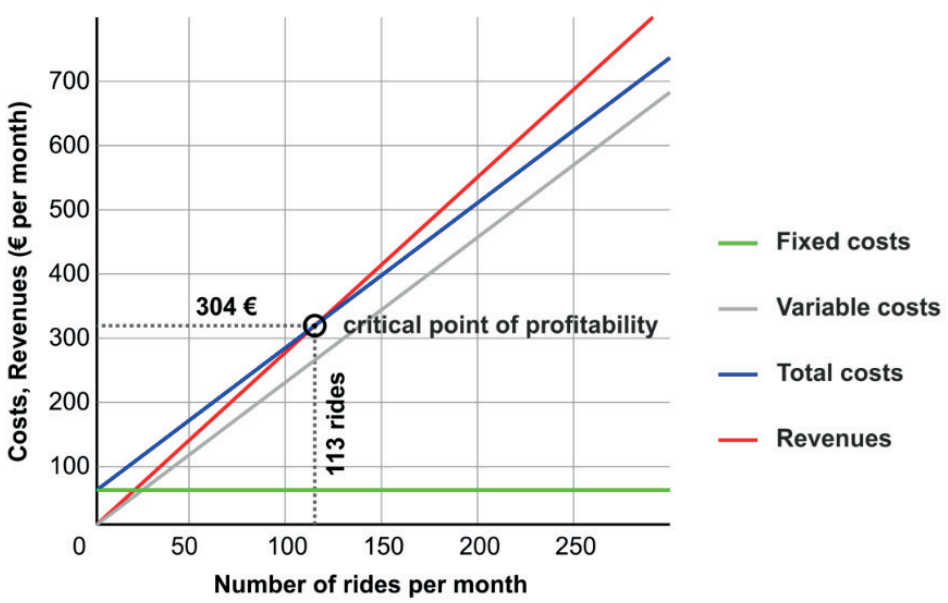

Figure 5 Graphical representation of the critical point of profitability

- the obligation to return the car to the place of rental.

The taxi service combines shared mobility with commercial passenger transport. The sustainability of a shared economy undoubtedly depends on the profitability of service providers. As an example, one could mention costs and revenues in the taxi business with the Bolt app. One of the authors provided a taxi service in this application. These results come from authors' own measurements.

Business in the road transport can be sustainable only if it is possible to reach the critical point of profitability. Its value is expressed as a number of rides per month. If the operator reaches this number of rides, his business will not be in profit or loss. It is not easy to calculate the revenues that flow from the taxi business with the Bolt app. Both supply and demand in the market are changing every day. Sometimes, there are many vehicles on-line and only a few customers. This ratio can change several times in one day. This calculation, based on real rides, estimates the rides utilization coefficient. The average distance of one passenger transport is $4.80 \mathrm{~km}$ and the average revenue is $€ 3.54$ per ride. However, one must highlight that Bolt's commission is at the level of $24 \%$. Therefore, one can consider the revenue of $€ 2.69$ per ride.

By accurately quantifying costs and analyzing revenues for the previous period, it is possible to perform a simple but accurate graphical analysis. It helps to find the critical point of profitability.

As can be seen from the chart, revenues are rising very slowly. Low fares, high commission and taxes cause this problem. The driver must complete 113 rides per month if he wants to obtain some business profit. The critical point of profitability describes this problem in Figure 5. Most of the time, however, the driver is online but out of work. For these waiting hours, he will not receive any financial compensation. The sustainability of this service is problematic. Bolt application gives some bonuses. Their purpose is to regulate the demand and supply, improve the economic attractiveness. There is a significant competition in this area of transport.
The price of the taxi service in the application must be lower than for other taxi services that use the traditional pricing method. On the other hand, some carriers need to cover their costs but cannot manipulate the price. The costs of drivers who operated a taxi service without any permits before 01-04-2019 included only:

- fuel costs,

- maintenance, repair and direct material costs, about telecommunication services.

- other costs connected with the operation of the car regardless of its use as a taxi vehicle.

After the amendment of Act no. 56/2012 on the road transport, this activity became a business according to a special regulation. Therefore, in addition to these costs, additional:

- entrance costs (concession, taxi driver's license, psycho tests, medical tests, taxi roof light, vehicle identification),

- costs of technical and emission check (for taxi vehicles once a year),

- accounting services,

- payment of value added tax $20 \%$ from the price of the application,

- health and social insurance,

- payment of income tax.

\section{Research and results}

Road transport provides the largest volume of transported passengers as well as goods. The road transport is the most widespread mode of passenger transport and accounts for $71 \%$ of all the passenger transports. The road transport also accounts for $51 \%$ of freight transport activities in the EU, followed by maritime transport with around $32 \%$ and rail with $11 \%$ [44].

The fundamental problem of the transport sector in the Slovak Republic is the long-term unfavorable development of model split between individual car transport and public transport. Slovak roads have 


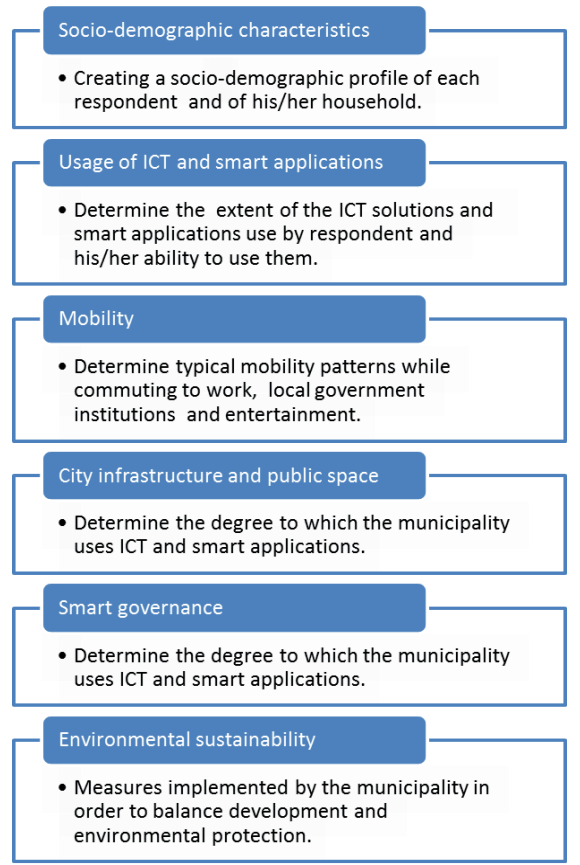

Figure 6 The main structure of the SCSPO survey [47]

a high degree of congestion due to increasing intensity, exceeding the proposed capacities, especially on motorways and the roads of class I [45].

In Slovakia, the number of registered vehicles increased by $30.33 \%$ over the last ten years (from $2,339,358$ to $3,357,695$ in 2020). Compared to the year 2019 , an increase of $2.17 \%$ was recorded [46]. The key parameter that influences individual car transport is the rising standard of living of the population and their growing demands for the quality of transport.

In the years 2010-2019, public transport represents only a third of the total transport performance in Slovakia. The disproportionate increase in individual car transport caused this fact. Personal car transport harms the road infrastructure and environment. In the last five years, the situation has stabilized relatively well and transport performance in public passenger transport has stagnation. However, the volume of individual car traffic continues to grow. On the other hand, one can see a slightly rising trend in the rail passenger transport as a positive phenomenon.

The traffic-sociological survey was performed and evaluated by authors. Its purpose was to obtain data on the citizen's opinions. Authors wanted to know views on Smart City approaches, policy and their impact on citizen's life. This section briefly introduces such a survey. Statistically evaluated results are presented in this section. The working name of the survey was "Smart City Solutions and Public Opinions" (SCSPO).

\subsection{Survey plan}

Authors have prepared the survey according to the scheme in Figure 6. The Smart City concept introduces many new technologies. Therefore, the list of our questions includes the issues related to mobility, smart applications and information and communication technologies.

Authors have skills with questionnaire surveys. In this case, authors had to conduct the survey through the internet. The idea was to obtain an as unbiased sample as possible, which was not a trivial task. The experimental part of a survey was conducted to check the questions and the approach. Therefore, the planned number of respondents was not achieved, calculated according to the sample size calculator.

The survey was conducted in the city of Zilina, a medium-sized city with population of about 80,000 .

As already mentioned, this survey did not include the completely representative sample. It was performed only for understanding the basic opinions and motivation of respondents. It was also used for verification of evaluation methods.

Authors wanted to know how demographic and sociological characteristics of population influence using of the modern technologies. The Probit and Logit models were used [48].

In the first part of the survey, the demographic information about the respondents was obtained. In the second part, the questions were put about the transport behavior of people. In the third part of the questionnaire, several questions were added about the smart technologies using. It was important to validate the questionnaire's appropriateness.

The questionnaire included more than thirty questions. The time necessary to correct fulfilling was about fifteen minutes. The first part of the survey lasted from 11.2. 2021 to 10.4. 2021. Up to two hundred invitations to complete the pilot survey were sent, 


\section{Cummulative Growth of Responses}

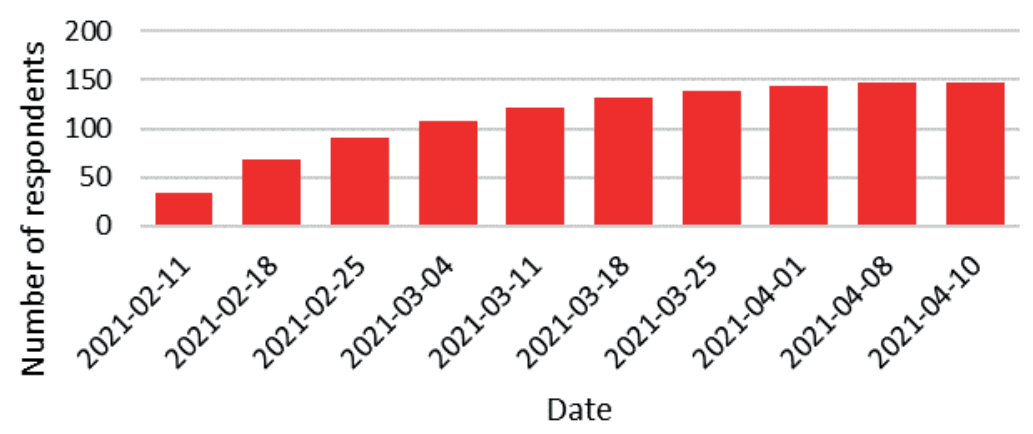

Figure 7 Response return histogram between 11-02-2021 and 10-04-2020

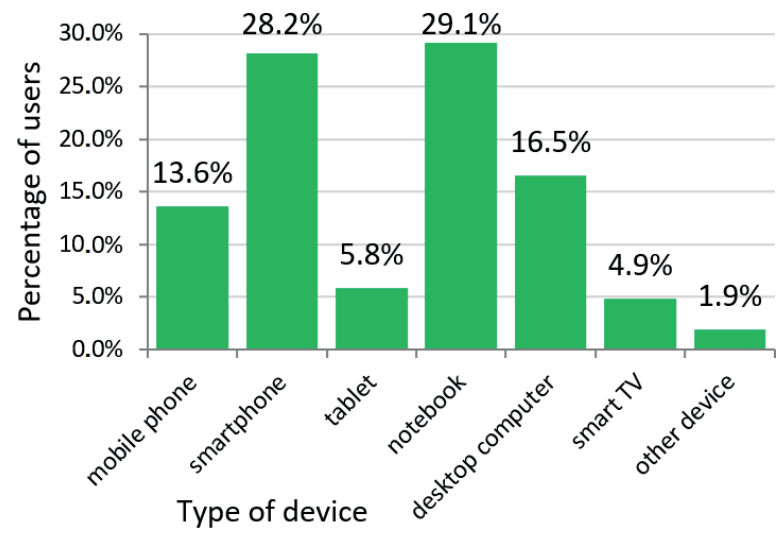

Figure $\mathbf{8}$ The most frequently used electronic devices of respondents

mainly to colleagues and students at the University of Zilina. About $50 \%$ of invitations were accepted. In Figure 7 is shown a histogram of recorded answers from the first to last day of the survey.

The introductory part of the questionnaire includes demographical and sociological data. The gender balance was quite good, $49 \%$ of respondents were male and $51 \%$ were female. The average respondent's age was 35 years. The university environment was surveyed, so there was a big group of respondents with a university degree (more than $90 \%$ ). About $66 \%$ of respondents have access to their private car.

During the survey, only $7 \%$ of people had a home office. More than eighty percent of people travel to work daily. It was found that the average transfer to work includes walking (less than 20 minutes) and 35 minutes spent in public transport. About $56 \%$ of respondents do not use public transport. It is due to problems with the unfit public transport timetable, connections and accessibility. Therefore, these people spend about half an hour per day driving their car.

In the third part, there were questions about the ICT devices. Our survey reveals that $70 \%$ of respondents can use more than $1000 \mathrm{MB}$ of mobile data per one month. More and more people can use the internet on their smartphones thanks to cheaper mobile services and better coverage of the $4 \mathrm{G} / 5 \mathrm{G}$ network. About $40 \%$ of respondents see themselves as "professional" smartphone users and $45 \%$ of respondents are "normal" users.

Then, the respondents were asked about the devices that they are using. Results are shown in Figure 8. Nowadays, the most common information and communication devices are a notebook and a smartphone. These two devices are used as a primary information hub by $60 \%$ of respondents. Respondents also use other devices as a typical mobile phone (14\%), desktop computer (17\%), tablet $(6 \%)$ and smart TV $(5 \%)$.

In the previous part of the research, it was found that one of the most important devices for people is a smartphone. Its use requires applications. Therefore, the question was included about paid applications for smartphones. Most respondents (57.6\%) accept only free smartphone applications. Other respondents are ready to pay for it, but $35.5 \%$ want to spend only a little money. Results are presented in Table 1.

Table 2 shows the opinions of respondents on the most important targets of investments. These targets relate to the first/last mile transport and can improve the model split of city inhabitants. 
Table 1 Opinions of respondents on paid applications

\begin{tabular}{lc}
\hline \multicolumn{1}{c}{ Answer } & Respondents \\
\hline Yes, I bought them regardless of price. & $6.9 \%$ \\
Yes, I buy them, but only when they are very cheap. & $35.5 \%$ \\
No, I have never bought paid applications. & $57.6 \%$ \\
\hline
\end{tabular}

Table 2 Investments, which can improve the quality of Smart City, transport

\begin{tabular}{|c|c|}
\hline Answer & Respondents \\
\hline transport structures & $43.9 \%$ \\
\hline parking solutions & $34.4 \%$ \\
\hline integrated transport system & $12.4 \%$ \\
\hline public transport & $12.2 \%$ \\
\hline bikesharing & $9.1 \%$ \\
\hline taxi services & $4.2 \%$ \\
\hline
\end{tabular}

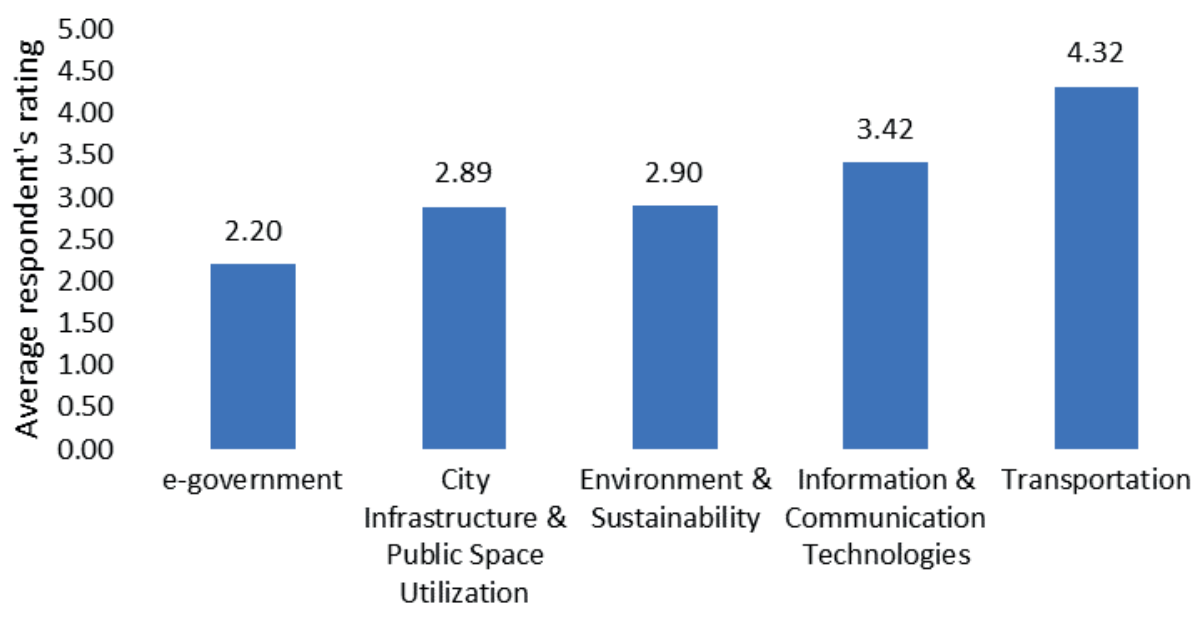

Smart City component

Figure 9 Perceived importance of Smart Cities components

One of the questions was about the Smart City pillars. Respondent evaluated each of the five pillars of the Smart City conception. This evaluation has five points, where the highest number means the highest importance. The results are shown in Figure 9.

The respondents were also asked for the feedback in this experimental part of the survey. That was necessary, since authors wanted to include them in another survey in Zilina. Thanks to feedback, authors could modify some questions in the list. The return ratio of the questionnaires was not poor, however, on the other hand, the collaboration with unknown people is not easy. Therefore, the essential part of the survey is a motivation for respondents. One effective way is to offer some symbolic compensation for the random respondents. According to the respondents, the questionnaire's conception, length and questions' wording affect the obtained data. The conducted survey confirmed the importance of transport in the concept of a Smart City.

\section{Conclusion}

This paper provides an overview of what are the user's values when considering the first/last mile part of their journey on public transport, which could be of value when deciding on improvement measures. The distance and costs are important issues that affect the selection of a type of transport [49].

By simultaneously considering the subjective requirements of users and more objective findings of environmental audits, it is possible to derive some priorities for measures to improve the first and last mile transport.

A few important transport systems were described in this paper, which will have important role in the Smart City concept. For example, bikesharing and carsharing systems can reduce greenhouse gases, so they can have a positive impact on environment [50-52]. The conducted survey revealed that only $3 \%$ of respondents use these systems. Bicycle as a means of transport to work is also 
not very common. Only $20 \%$ of respondents use it for regular traveling to work. The survey has shown that the bicycle is usually used for weekend occasional or regular trips (more than $40 \%$ of respondents).

An alternative way of transport described in this article was analyzed by many authors. They wrote studies, which included positive and many negative consequences of systems as carpooling, bikesharing and carsharing. These systems have positive impacts on the environment [53-54], bring reduced emissions [55], enhance the modal split [56], improve the first- and lastmile transport and [57] and improve mobility [58-59].

The bike-sharing systems are essential for the first- and last-mile transport. This research showed that using bicycles by Slovak citizens is not very common.
According to the literature [59-61], a bike should be a means that reduce the distance between home and public transport [62].

\section{Acknowledgement}

This publication was created thanks to support under the Operational Program Integrated Infrastructure for the project: Identification and possibilities of implementation of new technological measures in transport to achieve safe mobility during a pandemic caused by COVID-19 (ITMS code: 313011AUX5), co-financed by the European Regional Development Fund.

\section{References}

[1] ANAND, N., YANG, M., VAN DUIN, J. R., TAVASSZY, L. GenCLOn: an ontology for city logistics. Expert Systems with Applications [online]. 2012, 39(15), p. 11944-11960. ISSN 0957-4174. Available from: https://doi. org/10.1016/j.eswa.2012.03.068

[2] TANIGUCHI, E., THOMPSON, R. G., YAMADA, T. Recent trends and innovations in modelling city logistics. Procedia - Social and Behavioral Sciences [online]. 2014, 125, p. 4-14. ISSN 1877-0428. Available from: https:// doi.org/10.1016/j.sbspro.2014.01.1451

[3] MALHENE, N., TRENTINI, A., MARQUES, G., BURLAT, P. Freight consolidation centers for urban logistics solutions: the key role of interoperability. In: 6th IEEE International Conference on Digital Ecosystems and Technologies DEST 2012: proceedings [online]. IEEE. 2012. p. 1-6. Available from: https://ieeexplore.ieee.org/ stamp/stamp.jsp?arnumber $=6227939$

[4] LANGE, V., AUFFERMANN, C., MAHLSTEDT, K., MODE, S. Urban retail logistics-research into the bundled urban store deliveries of the future. In: Efficiency and logistics [online]. CLAUSEN, U., TEN HOMPEL, M., KLUMPP, M. (eds.). Berlin, Heidelberg: Springer, 2013. ISBN 978-3-642-32837-4, eISBN 978-3-642-32838-1, p. 109-119. Available from: https://doi.org/10.1007/978-3-642-32838-1_13

[5] DABLANC, L. City distribution, a key element of the urban economy: guidelines for practitioners. In: City distribution and urban freight transport: multiple perspectives [online]. MACHARIS, C., MELO, S. (eds.). UK: Edward Elgar Publishing Limited, 2011. ISBN 9780857932747, eISBN 9780857932754, p. 13-36. Available from: https://doi.org/10.4337/9780857932754.00007

[6] SLABINAC, M. Innovative solutions for a "last-mile" delivery-a European experience. In: 15th International Scientific Conference Business Logistics in Modern Management: proceedings [online]. 2015. Available from: https://hrcak.srce.hr/ojs/index.php/plusm/article/view/3876/2263

[7] NOWICKA, K. Smart city logistics on cloud computing model. Procedia - Social and Behavioral Sciences [online] 2014, 151, p. 266-281. ISSN 1877-0428. Available from: https://doi.org/10.1016/j.sbspro.2014.10.025

[8] RANIERI, L., DIGIESI, S., SILVESTRI, B., ROCCOTELLI, M. A review of last mile logistics innovations in an externalities cost reduction vision. Sustainability [online]. 2018, 10(3), 782. eISSN 2071-1050. Available from: https://doi.org/10.3390/su10030782

[9] SPERKA, A., VOJTEK, M., SIROKY, J., CAMAJ, J. Improvement of the last mile-specific issues in railway freight transport. Sustainability [online] 2020, 12(23), 10154. eISSN 2071-1050. Available from: https://doi. org/10.3390/su122310154

[10] COMI, A., SAVCHENKO, L. Last-mile delivering: analysis of environment-friendly transport. Sustainable Cities and Society [online] 2021, 74, 103213. ISSN 2210-6707. Available from: https://doi.org/10.1016/j.scs.2021.103213

[11] GEVAERS, R., VAN DE VOORDE, E., VANELSLANDER, T. Characteristics of innovations in last-mile logisticsusing best practices, case studies and making the link with green and sustainable logistics. In: European Transport Conference: proceedings [online], 2009. p. 1-21. Available from: http://citeseerx.ist.psu.edu/viewdoc/ download?doi=10.1.1.676.5843\&rep=rep1\&type=pdf

[12] STOPKA, O. Draft model of delivery routes at a city logistics scale when applying the Clarke-Wright method. The Archives of Automotive Engineering - Archiwum Motoryzacji [online]. 2020, 87(1), p. 67-80. eISSN 2084-476X. Available from: https:// doi.org/10.14669/am.vol87.art6 
[13] TANIGUCHI, E. Concepts of city logistics for sustainable and liveable cities. Procedia - Social and Behavioral Sciences [online] 2014, 151, p. 310-317. ISSN 1877-0428. Available from: https://doi.org/10.1016/j.sbspro.2014.10.029

[14] VISSER, J., NEMOTO, T., BROWNE, M. Home delivery and the impacts on urban freight transport: a review. Procedia - Social and Behavioral Sciences [online] 2014, 125, p. 15-27. ISSN 1877-0428. Available from: https:// doi.org/10.1016/j.sbspro.2014.01.1452

[15] NEGHABADI, P. D., SAMUEL, K. E., ESPINOUSE, M.-L. Systematic literature review on city logistics: overview, classification and analysis. International Journal of Production Research [online] 2019, 57(3), p. 865887. ISSN 0020-7543, eISSN 1366-588X. Available from: https://doi.org/10.1080/00207543.2018.1489153

[16] DABLANC, L. City logistics. In: International encyclopedia of geography: people, the earth, environment and technology [online]. John Wiley and Sons: 2016. ISBN 9780470659632, eISBN 9781118786352, p. 1-8. Available from: https://doi.org/10.1002/9781118786352

[17] KAUF, S. The Instruments of urban logistics and mobility management of population. Logistics and Transport. 2010, 10, p. 99-104. ISSN 1734-2015.

[18] NOCERA, S., PUNGILLO, G., BRUZZONE, F. How to evaluate and plan the freight-passengers first-last mile. Transport Policy [online] 2021, 113, p. 56-66. ISSN 0967-070X. Available from: https://doi.org/10.1016/j. tranpol.2020.01.007

[19] CHONG, Z. J., QIN, B., BANDYOPADHYAY, T., WONGPIROMSARN, T., RANKIN, E. S., ANG, M. H., LOW, K. H. Autonomous personal vehicle for the first-and last-mile transportation services. In: IEEE 5th International Conference on Cyber: proceedings [online]. IEEE. 2011. Available from: https://doi.org/10.1109/ ICCIS.2011.6070337

[20] CHEN, Y., WANG, H. Why are fairness concerns so important? lessons from a shared last-mile transportation system. Research Collection School of Computing and Information Systems [online] 2018. Available from: https:// ink.library.smu.edu.sg/sis_research/4029

[21] SHAHEEN, S., COHEN, A., MARTIN, E. US department of transportation's mobility on demand initiative: moving the economy with innovation and understanding. Transportation Research Circular (E-C231). 2018,

[22] WHITMORE, A., AGARWAL, A., DA XU, L. The internet of things - a survey of topics and trends. Information Systems Frontiers [online] 2018, 17(2), p. 261-274. ISSN 1387-3326, eISSN 1572-9419. Available from: https://doi. org/10.1007/s10796-014-9489-2

[23] ATZORI, L., IERA, A., MORABITO, G. The internet of things: a survey. Computer Networks [online] 2010, 54(15), p. 2787-2805. ISSN 1389-1286. Available from: https://doi.org/10.1016/j.comnet.2010.05.010

[24] SHAHEEN, S., CHAN, N. Mobility and the sharing economy: potential to facilitate the first-and last-mile public transit connections. Built Environment [online] 2016, 42(4), p. 573-588. ISSN 0263-7960. Available from: https:// doi.org/10.2148/benv.42.4.573

[25] JIN, S. T., KONG, H., WU, R., SUI, D. Z. Ridesourcing, the sharing economy and the future of cities. Cities [online]. 2018, 76, p. 96-104. ISSN 0264-2751. Available from: https://doi.org/10.1016/j.cities.2018.01.012

[26] VENTER, C. J. Measuring the quality of the first/last mile connection to public transport. Research in Transportation Economics [online] 2020, 83, 100949. ISSN 0739-8859. Available from: https://doi.org/10.1016/j. retrec.2020.100949

[27] LIU, Z., JIA, X., CHENG, W. Solving the last mile problem: ensure the success of public bicycle system in Beijing. Procedia - Social and Behavioral Sciences [online] 2012, 43, p. 73-78. ISSN 1877-0428. Available from: https:// doi.org/10.1016/j.sbspro.2012.04.079

[28] OLEJNIK, K. Study of the population in terms of knowledge about the distance between vehicles in motion. Open Engineering [online] 2021, 11(1), p. 310-318. ISSN 2391-5439. Available from: https://doi.org/10.1515/eng-20210031

[29] Population dynamics - Department of Economic and Social Affairs [online]. Available from: https://population. un.org/wpp/Download/SpecialAggregates/EconomicTrading/

[30] Global Perspectives Studies: Will global food and agricultural systems sustainably satisfy food and non-food agricultural demand? [online]. Available from: http://www.fao.org/global-perspectives-studies/en.

[31] The geography of EU discontent - European Commission [online]. Available from: https://ec.europa.eu/regional_ policy/en/information/publications/working-papers/2018/the-geography-of-eu-discontent

[32] Act on the Environment (Law No. 17/1992) [online]. Available from: https://www.ecolex.org/details/legislation/ act-on-the-environment-law-no-171992-lex-faoc004757/

[33] Horizontal principle of sustainable development [online]. Available from: https://www.partnerskadohoda.gov.sk/ data/att/868.pdf

[34] PRIBYL, O., SVITEK, M. System-oriented approach to smart cities. In: IEEE First International Smart Cities Conference ISC2 2015: proceedings [online]. IEEE. 2015. p. 1-8. Available from: https://doi.org/10.1109/ ISC2.2015.7428760 
[35] JOERSS, M., NEUHAUS, F., SCHRÖDER, J. How customer demands are reshaping last-mile delivery. The McKinsey Quarterly [online]. 2016, 17, p. 1-5. ISSN 0047-5394. Available from: https://www.mckinsey. com/industries/travel-logistics-and-infrastructure/our-insights/how-customer-demands-are-reshaping-last-miledelivery

[36] PRIBYL, O., GOULIAS, K. G. Simulation of daily activity patterns incorporating interactions within households: algorithm overview and performance. Transportation Research Record [online]. 2005, 1926(1), p. 135-141. ISSN 0361-1981, eISSN 2169-4052. Available from: https://doi.org/10.1177/0361198105192600116

[37] ARENTZE, T. A., TIMMERMANS, H. J. A learning-based transportation oriented simulation system. Transportation Research Part B: Methodological [online] 2004, 38(7), p. 613-633. ISSN 0191-2615. Available from: https://doi.org/10.1016/j.trb.2002.10.001

[38] Transport and storage - Statistical office of the SR [online]. Available from: https://slovak.statistics.sk/wps/portal/ ext/themes/sectoral/transport

[39] VOGEL, P., GREISER, T., MATTFELD, D. C. Understanding bike-sharing systems using data mining: exploring activity patterns. Procedia - Social and Behavioral Sciences [online] 2011, 20, p. 514-523. ISSN 1877-0428. Available from: https://doi.org/10.1016/j.sbspro.2011.08.058

[40] DADDIO, D. W. Maximizing bicycle sharing: an empirical analysis of capital bikeshare usage [online]. Master paper. 2012. Available from: https://doi.org/10.17615/qv32-b860

[41] JIMENEZ, P., NOGAL, M., CAULFIELD, B., PILLA, F. Perceptually important points of mobility patterns to characterise bike sharing systems: the Dublin case. Journal of Transport Geography [online]. 2016, 54, p. 228239. ISSN 0966-6923. Available from: https://doi.org/10.1016/j.jtrangeo.2016.06.010

[42] YANG, Y., HEPPENSTALL, A., TURNER, A., COMBER, A. A spatiotemporal and graph-based analysis of dockless bike sharing patterns to understand urban flows over the last mile. Computers, Environment and Urban Systems [online]. 2019, 77, 101361. ISSN 0198-9715. Available from: https://doi.org/10.1016/j.compenvurbsys.2019.101361

[43] DU, Y., DENG, F., LIAO, F. A model framework for discovering the spatio-temporal usage patterns of public free-floating bike-sharing system. Transportation Research Part C: Emerging Technologies [online] 2019, 103, p. 39-55. ISSN 0968-090X. Available from: https://doi.org/10.1016/j.trc.2019.04.006

[44] EU Transport in Figures: statistical pocketbook 2020 [online]. Available from: https://ec.europa.eu/transport/ facts-fundings/statistics/pocketbook-2020_en

[45] Strategic plan for the development of transport in the Slovak Republic until 2030 - MDVRR SR (in Slovak) [online]. Available from: https://www.opii.gov.sk/sea-sekcie/sea-strategicky-plan-rozvoja-dopravy-sr-do-roku-2030 -ii-phase

[46] Total number of registered vehicles in Slovakia - MV SR (in Slovak) [online] Available from: https://www.minv. sk/?celkovy-pocet-evidovanych-vozidiel-v-sr

[47] PRIBYL, O., HORAK, T. Individual perception of smart city strategies. In: Smart Cities Symposium Prague SCSP 2015: proceedings [online]. 2015. p. 1-6. IEEE. Available from: https://doi.org/10.1109/SCSP.2015.7181550

[48] BROWNSTONE, D., TRAIN, K. Forecasting new product penetration with flexible substitution patterns. Journal of Econometrics [online] 1998, 89(1-2), p. 109-129. ISSN 0304-4076. Available from: https://doi.org/10.1016/S03044076(98)00057-8

[49] RYAN, S., FRANK, L. F. Pedestrian environments and transit ridership. Journal of Public Transportation [online]. 2009, 12(1), p. 39-57. ISSN 1077-291X, eISSN 2375-0901. Available from: http://doi.org/10.5038/23750901.12.1.3

[50] CAULFIELD, B. Estimating the environmental benefits of ride-sharing: a case study of Dublin. Transportation Research Part D: Transport and Environment [online]. 2009, 14(7), p. 527-531. ISSN 1361-9209. Available from: https://doi.org/10.1016/j.trd.2009.07.008

[51] JUNG, J., KOO, Y. Analyzing the effects of car sharing services on the reduction of greenhouse gas (GHG) emissions. Sustainability [online]. 2018, 10(2), 539. eISSN 2071-1050. Available from: https://doi.org/10.3390/ su10020539

[52] GOGOLA, M. Analysing the vibration of bicycles on various road surfaces in the city of Zilina. The Archives of Automotive Engineering - Archiwum Motoryzacji [online] 2020, 88(2), p. 77-97. eISSN 2084-476X. Available from: https://doi.org/10.14669/am.vol88.art6

[53] MARTIN, E., SHAHEEN, S. A., LIDICKER, J. Impact of carsharing on household vehicle holdings: results from North American shared-use vehicle survey. Transportation Research Record [online]. 2010, 2143(1), p. 150-158. ISSN 0361-1981, eISSN 2169-4052. Available from: https://doi.org/10.3141/2143-19

[54] CHEN, T. D., KOCKELMAN, K. M. Carsharing's life-cycle impacts on energy use and greenhouse gas emissions. Transportation Research Part D: Transport and Environment [online]. 2016, 47, p. 276-284. ISSN 1361-9209. Available from: https://doi.org/10.1016/j.trd.2016.05.012 
[55] FIRNKORN, J., MULLER, M. What will be the environmental effects of new free-floating car-sharing systems? The case of car2go in Ulm. Ecological Economics [online]. 2011, 70(8), p. 1519-1528. ISSN 0921-8009. Available from: https://doi.org/10.1016/j.ecolecon.2011.03.014

[56] LOPEZ-ESCOLANO, C., CAMPOS, A. P., PARDOS, S. V., NEDELIAKOVA, E., STEFANCOVA, V. Incorporating bicycles into urban mobility: an opportunity for sustainable development. Communications - Scientific Letters of the University of Zilina [online]. 2017, 19(2), p. 68-73. ISSN 1335-4205, eISNN 2585-7878. Available from: http:// komunikacie.uniza.sk/index.php/communications/article/view/186

[57] SHAHEEN, S. A., COHEN, A. P., CHUNG, M. S. North American carsharing: 10-year retrospective. Transportation Research Record [online]. 2009, 2110(1), p. 35-44. ISSN 0361-1981, eISSN 2169-4052. Available from: https://doi.org/10.3141/2110-05

[58] CERVERO, R. City CarShare: first-year travel demand impacts. Transportation Research Record [online]. 2003, 1839(1), p. 159-166. ISSN 0361-1981, eISSN 2169-4052. Available from: https://doi.org/10.1016/j. jtrangeo.2017.11.018

[59] SABERI, M., GHAMAMI, M., GU, Y., SHOJAEI, M. H. S., FISHMAN, E. Understanding the impacts of a public transit disruption on bicycle sharing mobility patterns: a case of Tube strike in London. Journal of Transport Geography [online]. 2018, 66, p. 154-166. ISSN 0966-6923. Available from: https://doi.org/10.1016/j. jtrangeo.2017.11.018

[60] FISHMAN, E. Bikeshare: a review of recent literature. Transport Reviews [online]. 2016, 36(1), p. 92-113. ISSN 0144-1647, eISSN 1464-5327. Available from: https://doi.org/10.1080/01441647.2015.1033036

[61] SHAHEEN, S. A., GUZMAN, S., ZHANG, H. Bikesharing in Europe, the Americas and Asia: past, present and future. Transportation Research Record [online]. 2010, 2143(1), p. 159-167. ISSN 0361-1981, eISSN 2169-4052. Available from: https://doi.org/10.3141/2143-20

[62] WINSKA, M., GZIK, A. Determining the level of satisfaction among users of public transport in Lublin. The Archives of Automotive Engineering - Archiwum Motoryzacji [online]. 2019, 85(3), p. 19-39. eISSN 2084-476X. Available from: https://doi.org/10.14669/am.vol85.art2 